Article

\title{
Linkages Between acequia Farming and Rangeland Grazing in Traditional Agropastoral Communities of the Southwestern USA
}

\author{
Stephanie C. López ${ }^{1}$, Andrés F. Cibils ${ }^{2, *}$, Ursula R. Smedly ${ }^{3}$, Steven J. Guldan ${ }^{4}$, \\ Alexander G. Fernald ${ }^{2}$, Carlos G. Ochoa ${ }^{5}$ (i) , Kenneth G. Boykin ${ }^{6}$ and Lilian Cibils ${ }^{7}$ \\ 1 Formerly Department of Animal and Range Sciences, New Mexico State University, \\ Las Cruces, NM 88003, USA; stepnaielopez02@yahoo.com \\ 2 Department of Animal and Range Sciences, New Mexico State University, Las Cruces, NM 88003, USA; \\ afernald@nmsu.edu \\ 3 Formerly Sustainable Agriculture Science Center at Alcalde, New Mexico State University, \\ Alcalde, NM 87511, USA; usmeldy@taosnet.com \\ 4 Sustainable Agriculture Science Center at Alcalde, New Mexico State University, Alcalde, NM 87511, USA; \\ sguldan@nmsu.edu \\ 5 Department of Animal and Rangeland Sciences, Oregon State University, Corvallis, OR 97331, USA; \\ Carlos.Ochoa@oregonstate.edu \\ 6 Center for Applied Spatial Ecology, NM Cooperative Fish and Wildlife Research Unit, \\ New Mexico State University, Las Cruces, NM 88003, USA; kboykin@nmsu.edu \\ 7 Department of Curriculum \& Instruction, New Mexico State University, Las Cruces, NM 88003, USA; \\ lcibils@nmsu.edu \\ * Correspondence: acibils@nmsu.edu; Tel.: +1-575-646-4342
}

Received: 22 May 2018; Accepted: 12 June 2018; Published: 14 June 2018

\begin{abstract}
Many agropastoral systems worldwide are supported by important linkages between crop production and rangeland grazing. We explored the connections between smallholder farming and public rangeland grazing in northern New Mexico, USA. We retrieved historical data of livestock inventories, drought, and hay production which we analyzed using either ordinary least squares models, generalized autoregressive conditional heteroscedasticity models $(\mathrm{GARCH})$, or exponential GARCH models. We also conducted a survey of farmers and ranchers $(n=74)$ of traditional communities in our study area using a mixed methods design. County hay production was the only predictor that explained year-to-year variation in allotment livestock numbers. Allotments that increased livestock numbers tended to have larger base properties (mostly irrigated cropland). Most survey respondents (95\%) raised livestock and slightly more than half agreed that livestock provided better financial security than crops. Availability of summer grazing lands and ability to grow or purchase hay to feed livestock during winter were the factors cited least ( $6 \%$ of responses) and most (42\%), respectively, as limiting farmers' ability to increase their herd size. Livestock-raising apparently continues to be critical to the acequia agropastoral economy. Ability to acquire winter feed (hay) appears to regulate the demand for summer grazing on public forested rangelands.
\end{abstract}

Keywords: Parciantes; grazing allotments; pastoralism; smallholders; New Mexico

\section{Introduction}

Roughly half of the world's food is produced by smallholder agropastoralists who grow crops on small parcels of land and use native rangeland and crop residues to raise a few head of livestock [1]. In many of these systems, livestock serve the purpose of alleviating poverty [2], particularly in family-based subsistence agriculture [3]. Although small scale crop-rangeland mixed systems are 
common in developing countries [1,4,5], traditional agropastoralism also occurs in areas of the developed world such as the Swiss Alps [6-8], the Cantabrian and Pyrenees mountain ranges of northern Spain [9], the Mediterranean basin of Europe [10], and small valleys of the Rio Grande and its tributaries in northern New Mexico and southern Colorado in the southwestern USA [11].

Smallholder agropastoralism in north-central New Mexico (USA) is common among members of traditional Hispanic acequia communities, who grow irrigated crops in the valleys and use upland forests and woodlands to raise small herds of livestock. The term acequia, a Spanish word derived from the Arabic expression for water conduits [12], refers both to the community-maintained ditch irrigation systems that supply water for crops, livestock, and domestic consumption [13], and the locally-governed smallholder institutions that manage irrigation water use [14]. There are currently close to 800 acequia communities in New Mexico, many of which were established by the Spanish colonial authority in the late 17th century [11]. The capacity of these farmer-governed organizations to endure four centuries of dramatic socioeconomic and cultural change has elicited the attention of an array of scholars that have sought to understand their history and water governance traditions [11,15-18], the ecohydrology of the valleys they irrigate [19-23], the changes in irrigated land use patterns over time [13], and more recently, the biosocial limits to their resilience [12,14,24,25]. Much of the research conducted in this system, however, has been somewhat narrowly focused on either valley agriculture (references above) or upland livestock grazing [26-30], but no studies, to our knowledge, have attempted to address the valley-upland agropastoral system as a whole (but see [31]).

Similar to what occurs in other agropastoral economies worldwide [1], Hispanic settlers in semiarid New Mexico relied on livestock to ensure food security during periods of drought [26,32]. Spanish colonial community land grants in the region were deliberately designed to support small-scale agropastoral economies [11]. Settler families were granted a solar, a small privately-owned parcel of land on the non-irrigated side of an acequia to build their homes, and were awarded acreage of adjacent rangeland, known as cuarentas, intended to provide sufficient forage to sustain a dairy cow or to occasionally grow dryland crops [26]. In addition, settlers had access to communal abutting upland forests and woodlands where members of the land grant had both grazing and firewood gathering rights [26]. Consequently, rangeland-based livestock-raising became intricately woven into the acequia economy and deeply rooted in the cultural tradition of its members [11].

Although a few land grants still exist in New Mexico today [27,33,34], most acequias lost local control of common grazing lands during the late 19th and early 20th centuries when common ownership ceased to be recognized as legal and upland forests and rangelands were placed primarily under the jurisdiction of the United States Forest Service [28], or the United States Department of the Interior's Bureau of Land Management [33]. Today, many land grant heirs who still practice acequia irrigation farming in the valleys must lease public grazing lands, formerly common pastoral areas, to sustain their livestock [28]. Federal land management agencies have sought to accommodate traditional customs by providing Hispanic land grant heirs priority on land leasing, or allowing multiple user permits on allotments [27,28], but controversy and litigation over land tenure rights persist (e.g., [35,36]). Government-imposed shifts in grazing rights on common lands are a frequent stressor in pastoral systems worldwide [37] including the western United States, where ranching enterprises were historically shaped by periods of land tenure stability/instability [38]. Acequia communities were apparently able to adapt to the loss of local control of common grazing lands and maintain pastoral activities which are still thought to be locally important to the livelihood of some communities [17]. However, contemporary region-wide assessments of the role of rangeland-based livestock-raising in sustaining acequia farming are lacking.

The objective of this study was to assess the role of rangeland-based livestock-raising in supporting traditional acequia agropastoral communities of north-central New Mexico. More broadly, we sought to gain insight into livestock-mediated valley-upland connections and their contribution to the apparent resilience of these socio-agricultural systems. We used publicly available data to model the linkages between irrigated land use in the valley (acequia farming) and rangeland grazing in the upland and 
implemented a survey to understand how traditional farming systems of the region might influence the demand for livestock grazing pastures on surrounding rangelands.

\section{Materials and Methods}

Our study area included acequia farming communities and adjacent upland grazing allotments located within Rio Arriba and Taos counties in north-central New Mexico (see map in supplementary materials I) close to the localities of Alcalde $\left(36.09^{\circ} \mathrm{N} ; 106.06^{\circ} \mathrm{W}\right)$, El Rito $\left(36.32^{\circ} \mathrm{N} ; 106.16^{\circ} \mathrm{W}\right)$, and Rio Hondo-Valdez $\left(36.53^{\circ} \mathrm{N} ; 105.56^{\circ} \mathrm{W}\right)$. Alcalde is a small community that lies on the east side of the Rio Grande neighboring public grazing lands managed by the Bureau of Land Management. El Rito, surrounded by the Carson National Forest, was one of the first Spanish settlements of northern New Mexico [39] and is located on a tributary of the Rio Chama. Lastly, the community of Rio Hondo-Valdez is located north of Taos Valley on a tributary of the Rio Grande. This community rests at the foot of the Sangre de Cristo Mountains, bordering the Carson National Forest. Each site supports livestock production on both private and public grazing lands $[18,26]$. The communities of Alcalde, El Rito, and Rio Hondo-Valdez were selected because they: (a) encompass the regional variation in river hydrological regimes available in the region (Alcalde is on the main stem of the Rio Grande, while the other two sites occur on tributaries); and, (b) include communities that continue to practice traditional acequia irrigation, maintaining ancestral community-based water governance customs and institutions.

Annual average maximum and minimum temperatures in Alcalde are $20.1{ }^{\circ} \mathrm{C}$ and $1.1{ }^{\circ} \mathrm{C}$, respectively. Total annual rainfall is roughly $257 \mathrm{~mm}$ [40]. In El Rito, annual average maximum and minimum temperatures are $18.2^{\circ} \mathrm{C}$ and $2.9^{\circ} \mathrm{C}$, respectively, and total annual rainfall is $252 \mathrm{~mm}$ [40]. For Rio Hondo-Valdez, the annual average maximum and minimum temperatures are $17.6^{\circ} \mathrm{C}$ and $-0.5^{\circ} \mathrm{C}$, respectively, and total annual rainfall is approximately $312 \mathrm{~mm}$ [40]. July and August are the wettest months at all sites; 30 to $40 \%$ of the year's total precipitation occurs during that time of the year [40]. The entire region is exposed to periodic droughts of varying duration and intensity.

Data were gathered from two kinds of sources: (1) historical records of livestock inventories, drought, and hay production; and (2) a survey of farmers and ranchers of acequia communities in the study area. Thus, our study included both secondary (government statistics) and primary (surveys) data. Historical records were used to investigate valley-upland linkages, whereas the survey instrument assessed the role of livestock-raising on the resilience of acequia farming communities. We define resilience following ([41] p. 1), as 'the capacity of a system to absorb disturbance and reorganize while undergoing change so as to still retain essentially the same function, structure, identity, and feedbacks'.

\subsection{Historical Time Series Data}

County-level livestock and hay production data for Rio Arriba and Taos were retrieved from the United States Department of Agriculture National Agricultural Statistics Service online historical datasets [42]. Because no publicly-available farm- or acequia-level statistics exist, county-level data were used as our best proxy for relationships between long term trends in livestock numbers and valley hay production. The acequia-upland systems we studied are commonplace in Rio Arriba and Taos Counties. Virtually all of the hay produced in both these counties comes from irrigated farms in the valleys of the Rio Grande and its tributaries. Most of these farms are thought to be part of traditional acequias [11].

Livestock census data included cattle and sheep inventories from 1975 to 2011, whereas hay production data for both of these counties covered the 1975 to 2007 time period. Long-term drought data were retrieved from the National Oceanic and Atmospheric Administration (NOAA) website for New Mexico climatic division 2 which includes both Taos and Rio Arriba counties. Three drought indices were included in the analyses: Palmer Drought Severity Index (PDSI); Palmer Hydrological Drought Index (PHDI); and Modified Palmer Drought Severity Index (PMDI) [43]. 


\subsubsection{Land Cover Data}

Land cover data for Rio Arriba and Taos Counties obtained from the United States Geological Survey Gap Analysis Project [44] comprised satellite imagery (Landsat ETM+) from 1999 to 2001 combined with digital elevation model (DEM)-derived datasets to predict natural and semi-natural vegetation. Using the extract by mask toolset in ArcGIS 9 (ESRI, Redlands, CA, USA) the land cover grid file was clipped to the Rio Arriba and Taos county boundaries and then converted to a shape file. The area of each vegetation type within Rio Arriba and Taos counties and for each BLM and USFS allotment (see below) included in our study was calculated. At the county level, all vegetated non-cultivated and non-urban land was considered to have livestock grazing aptitude; thus, grazeable land-area estimates for Rio Arriba and Taos counties were 1,503,603 and 551,941 hectares, respectively.

Historical allotment-level data were obtained from the U.S. Department of Agriculture Forest Service (USFS) and the U.S. Department of the Interior Bureau of Land Management (BLM) Taos Field Offices. Forest Service data covered the period from 1936 to 2011 for 20 grazing allotments in the El Rito $(n=13)$ and Rio Hondo-Valdez $(n=7)$ study sites. No USFS grazing allotments were present in the upland areas adjacent to the Alcalde study site. Data retrieved from the Bureau of Land Management covered the period from 1960 to 2011 for 26 BLM grazing allotments surrounding the Alcalde $(n=10)$, El Rito $(n=8)$, and Rio Hondo-Valdez $(n=8)$ study sites. The average BLM and USFS allotment size was 4015 and 7950 hectares, respectively, and the total area covered by the 46 USFS and BLM allotments equaled 285,587 hectares.

\subsubsection{Stocking Rate Estimates}

Land cover data for Rio Arriba and Taos Counties obtained from the USGS Gap Analysis Project and USDA-NASS livestock inventory historical data sets were used to calculate county-wide stocking rates (SR) [44]. These were calculated as grazeable area per animal unit (see definition below) in any given year. We were unable to find reliable county-level estimates of land conversion rates, but expert knowledge of local county personnel indicated that grazeable area remained close-to-constant throughout the 1975-2011 period.

Data retrieved from each allotment included: (1) number and kind of animal units permitted; (2) number and kind of animal units actually grazed; (3) number of permittees per allotment; (4) area of home base property (deeded land owned by permittee; hectares); and (5) number of grazing permit transfers per allotment (the transfer of allotment grazing privileges from one permitee to another). All allotment data were gathered from the Grazing and Livestock Use Permit System Files, Rangeland Management Planning Files, and Permittee Folders. Allotment boundary layers were retrieved from the USFS Carson National Forest dataset available through the Southwestern Region Forest Service website [45], and the BLM rangeland allotment layer was obtained from the Bureau of Land Management website [46]. Land cover was also analyzed at the allotment level using the USGS data set described above (see Section 2.1.1.). We overlaid the USGS land cover map on our allotment maps to determine the area corresponding to each vegetation cover type which was expressed as a proportion of the allotment surface area.

To compute animal unit months (AUMs) for both allotment and county-level data in this study, we used the following equation:

$$
\text { AUM }=(\text { Total Days } / \text { Days in Month } \times \text { Number of Animals }) \times A U E
$$

Animal Unit Equivalent (AUE) was used to transform all livestock numbers to a standard unit $(1 \mathrm{AUE}=\mathrm{Cow}, 1.5 \mathrm{AUE}=$ Horse, and 0.2 AUE $=$ Sheep $)$. Livestock inventory data were then used in the equation to compute county-level stocking rates. All stocking rate data were expressed in Acres $\times \mathrm{AUM}^{-1}$. Given that Acres $\times \mathrm{AUM}^{-1}$ is a widely used and well understood metric of stocking rate across the western United States, no metric unit conversion was applied to this ratio. 


\subsubsection{Historical Time Series Data Analysis}

Stocking rate data at the county and study site levels were analyzed using Proc AUTOREG in SAS 9.2 (SAS Institute, Cary, NC, USA) to determine whether a number of factors of interest were significant predictors of year-to-year variation in SR. Year, growing season (June-August) drought indices for NM climatic division 2 (Palmer Drought Severity Index, Palmer Hydrological Drought Index, and Modified Palmer Drought Severity Index), and county-level hay production data were individually regressed against SR. Regression analyses for each study site were also conducted to determine if cattle market prices and SRs (between 1976 to 2010) explained variations in livestock numbers. This approach involved three types of cattle classes: steers $(136-181 \mathrm{~kg})$, heifers $(136-181 \mathrm{~kg})$, and mature bred cows. Cattle price data were retrieved from CattleFax [47]. Long-term trends were also examined by determining whether SR at the county-level and at each of our study sites had changed detectably over the past 24 to 40 years.

General Durbin Watson (DW) statistics were used to diagnose 1st to 10th order autocorrelation using the stepwise autoregression option. Both the Portmanteau Test statistic and the Engle Lagrange multiplier tests were used to diagnose heteroscedasticity at time lags (years) 1-12. If no autocorrelation or heteroscedasticity was detected ordinary least squares (OLS) regression was used to model the data. Generalized autoregressive conditional heteroscedasticity $(\mathrm{GARCH})$ models or exponential GARCH models were used when diagnostic tests indicated that errors were serially autocorrelated and heteroscedastic.

Analysis at the individual allotment level included a subset of 33 grazing allotments from all three study sites. Each of these allotments had more than 20 years of continuous stocking rate data. Diagnostic tests and modeling procedures described above were conducted to determine long term SR trend for each allotment. Subsequently, multiple regression analysis was conducted by regressing the slope of the function describing change in SR over time against a number of predictors including: allotment area (hectares); grazing permit type (multiple vs. individual); number of recorded grazing permit transfers; base property area (hectares); and proportion of vegetation land cover type on the allotment. A stepwise variable selection procedure was used to select the best subset of predictors. Variance inflation was calculated to diagnose colinearity among predictors. PROC REG in SAS 9.2 (SAS Institute, Cary, NC, USA) was used to conduct these analyses.

\subsection{Survey Data}

We used a mixed methods design [48] and developed a questionnaire based on unstructured informal interviews with community leaders and in consultation with a multidisciplinary research team comprised of agronomists, anthropologists, county extension agents, economists, hydrologists, rangeland scientists, and rural sociologists. Professionals from the U.S. Forest Service, the Bureau of Land Management, as well as members of the Northern New Mexico Stockmen's Association, and the Taos Valley Acequia Association provided input on the final version of the questionnaire. The New Mexico State University Institutional Review Board (IRB) approved the survey instrument and protocol used in this study.

As this study set out to identify the linkages between irrigated land use in the valley (acequia farming) and rangeland grazing in the upland, it was established that the population of interest consisted of small-scale livestock operators who owned irrigated farmland and leased federal grazing lands. Since no official registry of members of the population who combined both criteria was readily available, we could not develop a representative sampling frame or report a return rate. Instead, we designed an exploratory inquiry of a little-known population based on group characteristics. We used criterion-based sampling methods including time-location sampling that targets 'everyone present at a particular location during a particular time period' [48] (p. 286), and chain referral, by which key informants identify one or two members of the population who, in turn, help locate others [49] (p. 192). This network sampling method is recommended 'for studying hard-to-find or hard-to-study populations' [49] (p. 192). Respondents surveyed met at least one of the following four 
criteria: small-scale livestock operators who own irrigated farmland, and/or lease federal grazing lands, and/or are members of an acequia and/or grazing association. Thus, results of this survey can only be definitively used to describe the sampled respondents, rather than as representative of the larger population, or as basis for further generalization.

Approximately half the surveys were handed out at the Northern New Mexico Stockman's Association annual meeting in Taos in January 2013. This meeting is typically attended by ranchers and farmers with small to mid-sized livestock operations, most of whom are members of traditional Hispanic farming and ranching communities of the region. This portion of our survey involved using the time-location sampling strategy [43]. The remaining questionnaires were personally delivered shortly thereafter to farming households with the aid of New Mexico State University extension service personnel using the chain referral method [44]. The first stage in this method consisted of finding and contacting a household who met at least one of the target population criteria. Once the survey was completed, individual (s) were asked to help identify and introduce us to other individuals with similar characteristics or from the same subgroup of the population [50]. Therefore, survey participants included local community leaders, farmers, and ranchers from Taos Valley and from the Alcalde, El Rito, and Rio Hondo-Valdez areas.

The questionnaire included 27 multiple choice and five modified Likert scale questions which were divided into three main sections (See supplementary materials II): (1) Respondent demographics (age, gender, heritage, occupation, income source, and community participation); (2) Farm/Ranch operation characterization (livestock type, herd/flock size, summer grazing and winter feeding management, animal production marketing, size of farming operation, and crops grown); and, (3) Strategies and perceptions (drought and herd liquidation coping strategies, livestock contribution to income, family tradition, benefits of acequia membership, and access to public grazing lands).

Questionnaire data preparation began by grouping answers into broader categories $(n \leq 3)$ to facilitate statistical analyses of means (See supplementary materials III). Responses were subjected to Chi square analysis to determine whether response frequencies for a given question deviated detectably $(p \leq 0.05)$ from a uniform distribution. Contingency tables were also built to determine whether a respondent's perceptions and strategies were detectably associated $(p \leq 0.05)$ with her/his demographics or farm/ranch operation characteristics. JMP 10.0.2 (SAS Institute, Cary, NC, USA) was used to conduct Chi-square and contingency table analyses.

\section{Results}

\subsection{Historical Data}

Long-term mean stocking rates (Ac/AUM $\pm \mathrm{SEM}$ ) for the Alcalde, El Rito, and Rio Hondo upland grazing allotments were $20.4 \pm 1.5$ ( $n=41$ years, $33.7 \pm 1.1$ ( $n=35$ years), and $69.3 \pm 4.9$ ( $n=28$ years), respectively. These stocking rates were considerably lower than the county-wide rates $(\mathrm{Ac} / \mathrm{AUM} \pm \mathrm{SEM})$ of $13.62 \pm 0.92$ and $9.96 \pm 0.43$ for Taos and Rio Arriba counties, respectively.

A statistically detectable decrease in livestock numbers (i.e., an increase in acres per AUM) in both Taos and Rio Arriba counties was observed over the 35y period analyzed (Figure 1). However, stocking rates either remained unchanged in the rangeland allotments surrounding Alcalde acequias ( $\beta=-0.02 ; p=0.91)$, increased in allotments adjacent to El Rito acequias $(\beta=-0.35 ; p<0.01)$, or decreased in forest allotments above Rio Hondo-Valdez acequias $(\beta=1.11 ; p<0.01)$ (Table 1 , Figure 2). Hay production showed an increasing trend in both counties until the year 2000; a marked slump in production, which occurred between that year and 2005 (Figure 3) caused the long-term trend to differ between counties. Whereas Taos county suffered a statistically detectable long-term decrease in hay production $(\beta=-85.92 ; p<0.01)$, the opposite was true for Rio Arriba county $(\beta=176.32$; $p<0.01)$. 
County-level decline in livestock numbers coincided with the observed slump in hay production which occurred in the early 2000s. Furthermore, hay production at the county-level was the only significant predictor of year-to-year variation in stocking rates on rangeland allotments adjacent to Alcalde $(\beta=-0.0003 ; p=0.03)$, El Rito $(\beta=-0.0008 ; p<0.01)$, and Rio Hondo-Valdez $(\beta=-0.0013$; $p=0.01$ ) acequia communities (Table 1 ). This variable explained more than half of the year-to-year variation in stocking rates of rangelands above El Rito acequias (55\%), but only $24 \%$ and $14 \%$ of the variation in stocking rates of rangelands surrounding Rio Hondo-Valdez and Alcalde acequias, respectively (Table 1). None of the three drought indices considered in our analysis were significant predictors of annual stocking rate fluctuations (Table 1). OLS regression models showed no relationship between cattle prices and year-to-year variation in stocking rates at any of our study sites (data not shown).

Out of the 33 allotments across all three study sites that had more than 20 years of continuous stocking rate data, 10 allotments experienced a decrease in stocking rates, 12 increased their animal numbers, and the remaining 11 allotments showed no change in stocking rates over the period analyzed. Base property area, number of grazing permit transfers, and proportion of the allotment covered by piñon juniper (PJ) woodlands explained $90 \%$ of the long-term variation in stocking rates. Smaller base property area, higher number of permit transfers and higher proportion of PJ woodlands were all associated with a long-term decrease in stocking rates (Table 2).

Table 1. Factors associated with historical trends in stocking rates of cattle, sheep, and horses in allotments located on upland watersheds surrounding Alcalde, El Rito, and Rio Hondo acequia irrigation study areas. Predictors were modeled individually using either ordinary least squares models (OLS), a generalized autoregressive conditional heteroscedasticity model (GARCH) or an exponential GARCH (EGARCH).

\begin{tabular}{|c|c|c|c|c|c|}
\hline Study Site & Predictors & Model & $\beta$ & $p$ & $\mathbf{R}^{2}$ \\
\hline \multirow{6}{*}{ Alcalde } & Year & OLS & -0.0173 & 0.91 & \multirow[b]{6}{*}{0.14} \\
\hline & PDSI & OLS & 0.4824 & 0.55 & \\
\hline & PHDI & OLS & 0.9783 & 0.19 & \\
\hline & PMDSI & OLS & 0.7195 & 0.39 & \\
\hline & Hay Rio Arriba & OLS & -0.0002 & 0.30 & \\
\hline & Hay Taos & OLS & -0.0003 & 0.03 & \\
\hline \multirow{6}{*}{ El Rito } & Year & EGARCH & \multirow[t]{4}{*}{-0.3543} & $<0.01$ & \multirow[t]{4}{*}{0.49} \\
\hline & PDSI & GARCH & & 0.72 & \\
\hline & PHDI & GARCH & & 0.88 & \\
\hline & PMDSI & GARCH & & 0.72 & \\
\hline & Hay Rio Arriba & EGARCH & -0.0008 & $<0.01$ & 0.48 \\
\hline & Hay Taos & EGARCH & -0.0003 & $<0.01$ & 0.55 \\
\hline \multirow{6}{*}{ Rio Hondo } & Year & EGARCH & 1.1100 & $<0.01$ & \multirow[t]{5}{*}{0.11} \\
\hline & PDSI & OLS & 2.8200 & 0.31 & \\
\hline & PHDI & OLS & 1.2787 & 0.63 & \\
\hline & PMDSI & OLS & 2.0908 & 0.48 & \\
\hline & Hay Rio Arriba & OLS & -0.0018 & 0.12 & \\
\hline & Hay Taos & OLS & -0.0013 & 0.01 & 0.24 \\
\hline
\end{tabular}




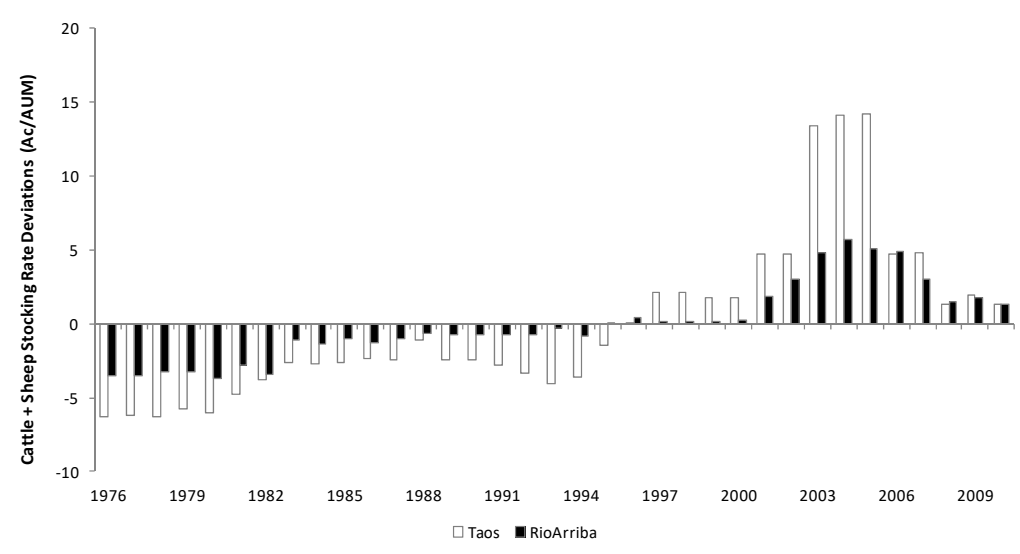

Figure 1. Annual deviation from estimated cattle + sheep long term (35 years) stocking rates for Taos and Rio Arriba counties (negative = more livestock; positive = less livestock). Mean stocking rates \pm SEM for this period were $13.62 \pm 0.92$, and $9.96 \pm 0.43$ Ac/AUM for Taos and Rio Arriba counties, respectively.

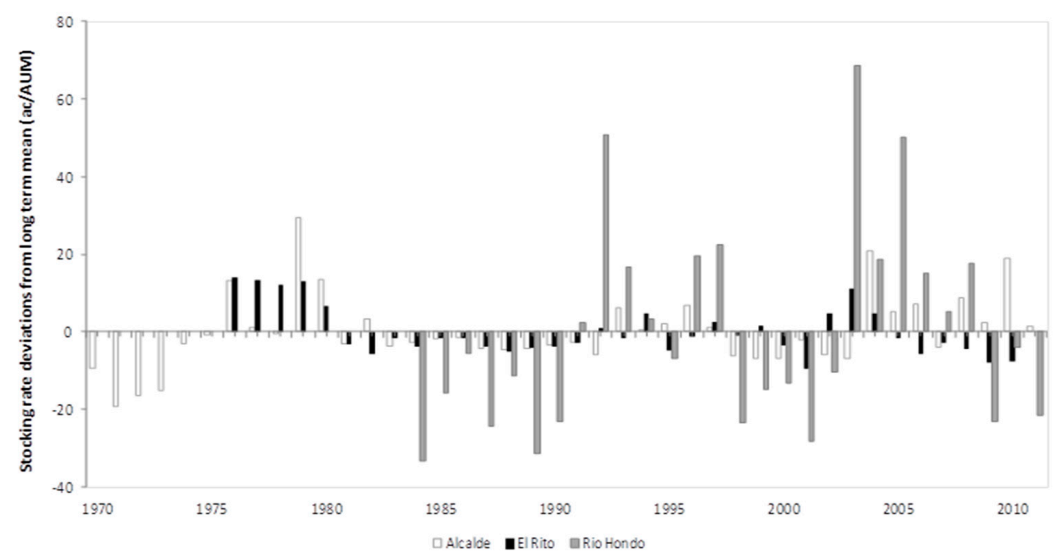

Figure 2. Annual deviation from long term stocking averages on allotments located on upland watersheds surrounding Alcalde, El Rito, and Rio Hondo acequia irrigation study areas (negative $=$ more livestock; positive $=$ less livestock). Mean stocking rates (Ac/AUM) \pm SEM for this period were $20.4 \pm 1.5$ ( $n=41$ years), $33.7 \pm 1.1$ ( $n=35$ years), and $69.3 \pm 4.9$ ( $n=28$ years) for the Alcalde, El Rito, and Rio Hondo upland grazing allotments, respectively.

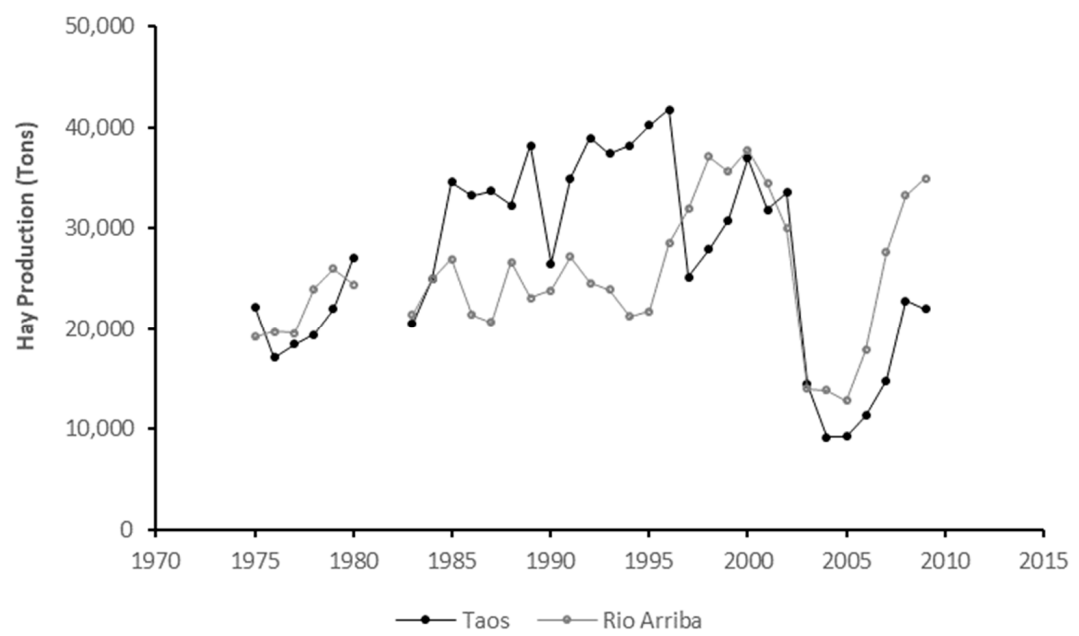

Figure 3. Long-term annual hay production in Taos and Rio Arriba counties according to the United States Department of Agriculture National Agricultural Statistics Service. 
Table 2. Multiple regression model including a set of predictors of long-term ( $\geq 20 \mathrm{y})$ changes in stocking rates (Acres $\times \mathrm{AUM}^{-1}$ ) at the level of individual grazing allotments located on upland rangeland surrounding Alcalde, El Rito, and Rio Hondo-Valdez acequia irrigation study areas.

\begin{tabular}{cccc}
\hline Variable & $\boldsymbol{\beta} \pm \mathrm{SE}$ & $\boldsymbol{p}$ & VIF \\
\hline Base Property Area (acres) & $-0.32 \pm 0.04$ & $<0.01$ & 1.22 \\
Number of Grazing Permit Transfers & $10.72 \pm 2.10$ & $<0.01$ & 1.17 \\
Proportion of allot. covered by PJ ${ }^{1}$ & $259.05 \pm 76.86$ & 0.01 & 1.24 \\
Model & 0.90 & & \\
$R^{2}$ & $<$ & $<0.01$ & \\
\hline
\end{tabular}

${ }^{1}$ Piñon Juniper woodlands (PJ).

\subsection{Survey Responses}

A total of 74 questionnaires were completed by participants who were either present at the Northern New Mexico Stockman's Association annual meeting $(n=49)$, or who were visited in their homes $(n=25)$ in El Rito $(n=15)$, Rio Hondo-Valdez $(n=6)$, and Alcalde $(n=4)$ study areas. All participants met at least one of our four selection criteria. Some participants did not provide answers to all questions, therefore the number of individual question responses received ranged between 74 and 50, except for those addressing sheep production and marketing which had the lowest response rate (13 to 23$)$.

Ninety percent of survey respondents were 45 years or older (approximately one third of them were 65 years or older) and $87 \%$ of participants were men. Seventy-three percent of individuals self-identified as either farmers $(33 \%)$, ranchers $(15 \%)$, or both $(25 \%)$, whereas retirees accounted for $20 \%$ of the surveyed population. Off-farm employment or retirement, however, was identified by $71 \%$ of respondents in our sample as the main source of family income. Ninety-four percent of participants belonged to families that had ranched and/or farmed for multiple generations. Ninety-one percent of respondents also indicated that they acquired the skills needed to ranch and/or farm from elder family members. Ninety-three percent of survey participants were members of either an acequia association $(19 \%)$, a grazing association (20\%), or both $(54 \%)$. Close to $70 \%$ of the surveyed sample population self-identified as active members of community organizations such as churches, schools, local fire departments, among others.

Ninety-five percent of surveyed participants raised livestock. Most raised cattle only, whereas a few respondents $(15 \%)$ raised both cattle and sheep. Cow-calf operations were the most common livestock enterprise ( $80 \%$ of respondents). Fifty-two percent of the surveyed respondents declared herds of less than 50 head of cattle; two thirds of these participants owned 20 head or less. Seventy-four percent of respondents that raised sheep and cattle owned flocks of less than 25 head of sheep. Eighty-three percent of surveyed participants described themselves as "hands on" managers, and more than two thirds (68\%) indicated that their families helped with livestock management chores on a regular basis.

Sixty-six percent of respondents leased public grazing lands. Most of these individuals grazed both public and private lands (public primarily in summer and private primarily in winter), whereas a minority $(6 \%)$ depended solely on public grazing lands. Sixty-eight percent of respondents that leased public grazing lands held a joint permit on the grazing allotment (i.e., their livestock were part of a multiple-owner herd/flock). Sixty-four percent of respondents that leased public grazing lands owned a base property (privately owned land, usually the farm/ranch headquarters) located less than 30 miles from the grazing allotment.

Half of respondents who raised livestock reported that their herd/flock size had decreased over the past fifteen years. The remaining half was evenly divided between those reporting no change and those who had increased the size of their herd/flock. The single most frequently cited factor $(42 \%)$ limiting respondents' ability to increase herd/flock numbers was the capacity to grow or purchase hay 
to feed livestock during winter months. Droughts and availability of summer grazing lands, on the other hand, were the least frequently cited factors ( $18 \%$ and $6 \%$, respectively).

More than half of the surveyed population who farmed irrigated land $(n=65 ; 58 \%)$ owned more than 20 acres of farmland. Thirty-one percent owned 5-20 acres of irrigated land, and a small proportion of respondents (11\%) owned less than five acres. Most respondents that owned irrigated land grew hay $(91 \%)$; most used it as forage for their livestock $(77 \%)$ but in a few cases $(14 \%)$ hay was grown mostly for sale.

The most frequent strategy adopted by survey participants to cope with drought consisted of a combination of purchasing or storing forage and reducing herd numbers (Figure 4). Purchasing forage and selling livestock were the most and least utilized strategies, respectively (Figure 4). Respondents who were members of acequia associations were the most likely to store forage reserves, whereas members of grazing associations were more likely to purchase hay (Chi $\left.{ }^{2}: 18.51 ; p: 0.03\right)$. Respondents with intermediate cattle herds (20 to 50 head) were more likely to sell livestock in a drought; whereas participants with small ( $<20$ head) and large ( $>50$ head) herds were more likely to either store (small herds) or purchase (large herds) forage to cope with droughts (Chi ${ }^{2}: 17.96 ; p: 0.01$ ). Individuals whose livestock grazed on private lands were the most likely to sell livestock in a drought. Conversely, individuals who leased public grazing lands were more prone to feed forage, either stored or purchased, to mitigate the effects of drought $\left(\mathrm{Chi}^{2}: 12.95 ; p\right.$ : 0.04). Respondents with 'hands on' management styles were more likely to adopt a mix of strategies involving both feeding and culling to cope with drought, whereas individuals with 'hands off' or a mix of hands on/off management styles were less likely to sell livestock and more prone to feed either purchased or stored forage (Chi ${ }^{2}: 14.81$; $p: 0.02)$.

If individuals had no choice but to liquidate their livestock, ninety-seven percent of respondents indicated that they would be unwilling to sell their farmland (Figure 4). Sixty-six percent would continue to grow hay for sale, a quarter would give up farming but maintain ownership of their fallow irrigated farmland, whereas a minority (5\%) would grow other crops (Figure 4$)$. Only respondents who self-identified as ranchers, or whose herd numbers had declined over the past 15 years, were likely to sell their irrigated farmland if forced to liquidate their livestock. Those who self-identified as farmers, rancher/farmers, retirees, or other, or whose herd numbers had increased over the past 15 years, were much more likely to maintain ownership of their lands and, in most cases, grow hay for sale $\left(\mathrm{Chi}^{2}: 28.29 ; p\right.$ : 0.01).

Respondents who raised both sheep and cattle were more likely to either sell their land or grow crops other than hay if forced to sell off all their livestock $\left(\mathrm{Chi}^{2}: 10.38 ; p: 0.02\right)$. All participants owning small farms (<20 ha) would adopt strategies that did not involve losing farm ownership, whereas a minority of larger farm owners would consider selling their land if forced to sell off all their livestock ( $\mathrm{Chi}^{2}:$ 15.37; $p$ : 0.02). Small farm owners were much more likely to maintain their farms fallow compared with large farm respondents who were more likely to grow hay for sale $\left(\mathrm{Chi}^{2}: 17.18\right.$; $p$ : 0.01). Only respondents who currently grew hay to feed their livestock indicated that they would consider selling their irrigated land if forced to liquidate their herd $\left(\mathrm{Chi}^{2}: 16.68 ; p: 0.01\right)$.

Slightly more than half of participants surveyed agreed that owning livestock provides better financial security than growing irrigated crops; very few respondents (13\%) disagreed with this notion (Figure 5). Respondents who self-identified as farmers ( $\left.\mathrm{Chi}^{2}: 23.54 ; p: 0.02\right)$, or who owned small herds of cattle ( $<50$ head, $\left.\mathrm{Chi}^{2}: 8.96 ; p: 0.06\right)$, or who grazed livestock close to their base property ( $<30$ miles, $\mathrm{Chi}^{2}: 7.50 ; p: 0.02$ ) were more likely to disagree with the view that livestock provide better financial stability than crops. Conversely, participants who described themselves as being both a farmer and a rancher, or that owned a large herd of cattle ( $>50$ head), or whose grazing lands were far from the base property ( $>30$ miles) were the groups who supported this idea the most. 


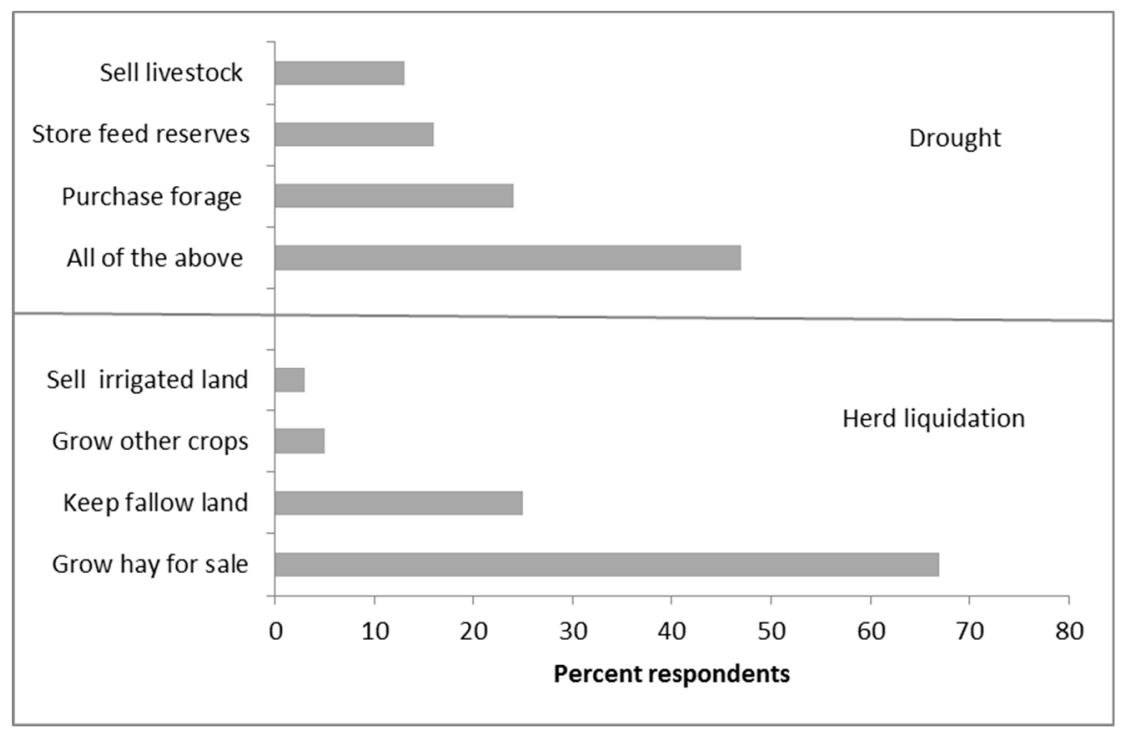

Figure 4. Strategies of agropastoralists of our study area in north-central New Mexico to cope with drought (above) and livestock herd liquidation (below).

Most surveyed individuals who grazed their livestock close to their base property $(<30$ miles) also declared off-farm income as their most important source of livelihood. Eighty-four percent of surveyed individuals agreed that livestock-raising was a family tradition (Figure 5). Most participants indicated that their involvement in an acequia association was beneficial to their livestock operation and very few respondents viewed access to public grazing lands as a driving motive to own irrigated lands (Figure 5).

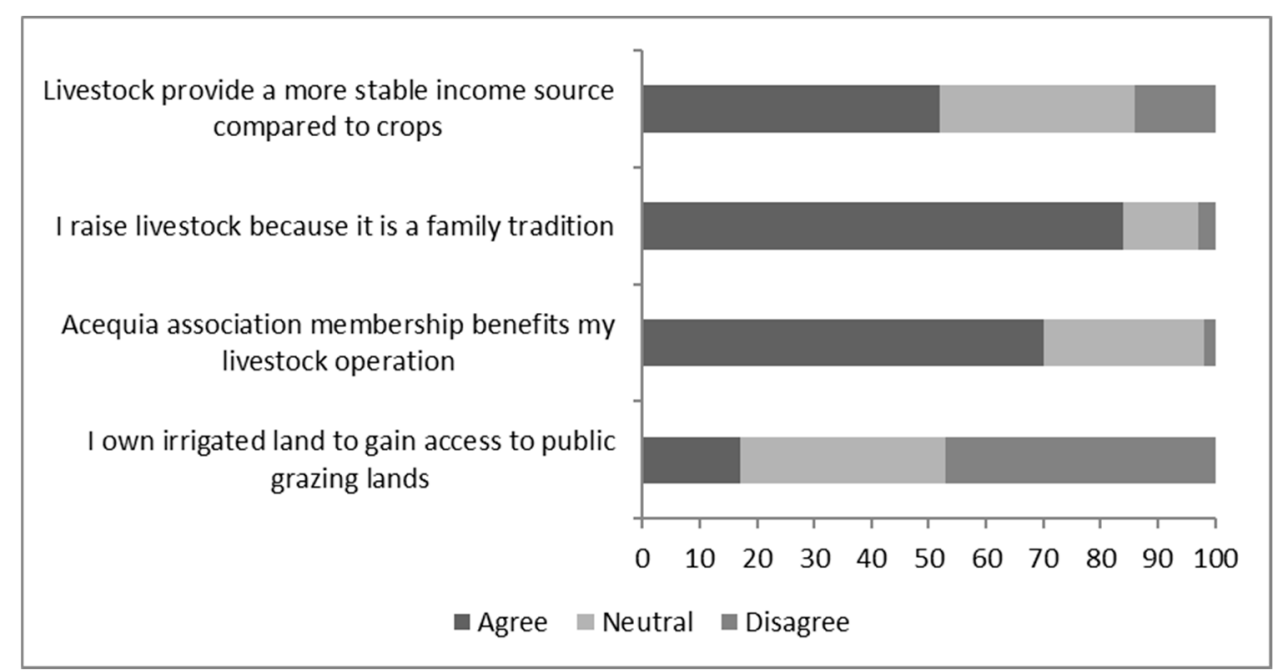

Figure 5. Perceptions of agropastoralists of our study area in north-central New Mexico regarding the role of livestock (top two bars) and the links between irrigation farming and livestock production (bottom two bars).

\section{Discussion}

Analysis of time series data from a number of independent sources (NOAA, USDA-NASS, USDA-USFS, and USDI-BLM) showed intriguing connections between valley hay production and upland livestock grazing. The driest year of the historical time series we analyzed (2002; PDSI-3.8) coincided with a hay production nadir in both Rio Arriba and Taos Counties and preceded a 
stocking rate nadir in both counties, but especially Taos. Allotments surrounding our study sites did not experience significant declines in livestock numbers in the early 2000s (note that study site allotments were stocked very lightly compared with county-wide rates), nonetheless, county hay production, our best proxy for availability of valley hay at each site, was the only factor out of several predictors analyzed that was detectably associated with stocking rate fluctuations at all three sites. Interestingly, the strongest positive relationships between hay production and rangeland stocking rates occurred at the El Rio site which included only summer grazed USFS allotments. Conversely, the weakest valley hay-rangeland stocking rate relationship was found in allotments surrounding Alcalde, almost all of which consisted of winter- or spring-grazed BLM rangeland. The Taos study site, which exhibited intermediate strength in valley hay-upland stocking rate relationships, included a mix of summer-grazed USFS allotments and winter-grazed BLM rangeland.

Valley hay-upland grazing connections emerged once again in our analysis of individual allotments. The size of the base property (irrigated farm area) partially explained why cattle numbers increased on some allotments yet decreased on others. Smaller base properties (limited ability to grow hay) were associated with long term declines in allotment stocking rates, whereas the converse was true of allotments with larger home base properties. Increased woodland encroachment in the uplands (PJ cover) and land tenure instability (number of permit transfers) were also associated with decreasing stocking rates on allotments. These trends are consistent with region-wide research results that show associations between declines in livestock numbers and each of these factors $[37,38,51]$.

Regardless of whether participants self-identified as farmers, ranchers, or both, $95 \%$ of survey respondents raised livestock (mostly cow-calf), $90 \%$ of participants who owned irrigated land grew hay (mostly to feed their livestock), and close to two thirds of participants leased rangeland from the federal government to graze their livestock during part of the year. A majority of the latter held joint grazing permits and were members of acequia and/or grazing associations. As in the early days of Spanish colonial settlement, contemporary acequia communities continue to rely on agricultural endeavors that involve strategic integration of upland and valley natural systems. Current day small-scale pastoral enterprises (52\% of respondents owned less than 50 head of cattle) appear to not only provide a means of connecting the use of these two types of land, but also of maintaining family traditions and fostering community cohesiveness, both of which emerged as important cultural values among survey participants in this and in previous studies [26,27,30,32].

More than half of survey participants in our study agreed with the notion that raising livestock provides better financial security than growing crops. For most farmers engaged in smallholder agropastoralism worldwide, livestock are not only a tradeable commodity but also serve as a preferred wealth store [52,53] and a source of cash in hand to cover household emergencies [3] or as an insurance to mitigate the consequences of crop loss during droughts [54]. Similarly, small-scale Hispanic farmers of northern New Mexico view livestock "as banks-on-the-hoof, which can be used in hard times" and serve "as a back-up resource for emergencies, for periods of unemployment, or for special needs such as college tuition for the children" ([27] p. 543).

In small-scale agropastoral systems worldwide, income from crops usually outweighs livestock contributions to the household economy [1]. Conversely, acequia farmers in our study area appear to have become increasingly less food crop-reliant and more engaged in pastoralism. Historically, acequia communities grew a wider variety of crops including beans, wheat, maize, and alfalfa [27] but throughout the second half of the 20th century, in some valleys parcels of farmland became larger [14] and percentage of irrigated land used to grow hay, particularly alfalfa, increased steadily [13]. Less than $10 \%$ of survey respondents in this study grew crops other than hay and when asked about preferred strategies in an extreme situation of forced herd liquidation, very few participants $(5 \%)$ viewed switching to other crops as a viable alternative. Most survey respondents indicated that they would continue to grow hay for sale. The fact that for most respondents off-farm employment or retirement was the main source of family income, a phenomenon somewhat analogous to out-migrant 
remittances in developing world agropastoralism (e.g., [55,56]), perhaps explains the transition toward less time-consuming pastoral-based farming systems.

Despite a historical sharp decline in public land grazing permits [14,27], a fact often cited in land tenure litigations [33], only half of survey respondents reported that their herd/flock numbers had decreased over the past fifteen years. The remaining half was evenly divided between those reporting no change (25\%) and those who had seen an increase in the size of their herd/flock (25\%). Recent herd dynamics, however, were significantly associated with a respondent's apparent willingness to sell their ancestral irrigated land and presumably abandon the acequia-centered life style if forced to liquidate their livestock. The very few respondents (3\%) who expressed willingness to sell their farmland were individuals who had seen their livestock herd wane in recent years. This finding, while numerically minor, might not be trivial in terms of community resilience. Further research is needed to determine the connections between loss of livestock and the decision to abandon acequia farming in our region.

Given the long history of litigation over rangeland tenure rights between heirs of Spanish and Mexican Land Grants and the federal government [26-28,33], we were surprised to find that availability of summer grazing lands (almost entirely public lands) was the least frequently cited factor $(6 \%$ of responses) limiting respondents' ability to increase the size of their livestock herds. The capacity to grow or purchase hay to feed livestock through the winter months was the single most frequently cited factor ( $42 \%$ of responses). Although winter or dry season forage bottlenecks are common in most pasture-based livestock systems around the world [57] and even though it is well known that supplement feed is the costliest element of rangeland-based cow-calf operations [58], the apparent central role of hay in regulating livestock numbers across our study area (as shown in our historical data analyses) was somewhat unexpected.

Among examples of long-enduring common pool resources (CPRs), the Nobel Prize economist Elinor Ostrom [6] highlighted the case of communal grazing land tenure of high altitude meadows and forests of Tröbel, Switzerland. In those systems, which date back to the 13th century, farmers plant crops (including hay) on privately owned land and communally graze the uplands. Interestingly, upland grazing regulations established as early as the 16th century, stipulated that "no citizen could send more cows to the alp than he could feed during the winter" [8] (p. 139), a land use practice that is thought to explain why these agropastoral communities were able to endure centuries of socio-ecological change. The New Mexico acequia systems we studied appeared to exhibit some of the core elements of the secret to Tröbel's endurance [6]; i.e., production of forage for winter use appeared to regulate levels of summer livestock herbivory in the upland. Initially, public land permits in the USA had similar stipulations to those of Tröbel; however, the Swiss agropastoral villages [6] and the systems we studied are possibly different in terms of spatial connectivity of agricultural production of valleys and adjacent uplands. Only about a third of survey respondents (data not shown) in our study grazed their livestock on public lands within 10 miles of their base property (irrigated land).

We suspect that since the days of Spanish and Mexican Land Grants [26], acequia pastoralism has experienced increasing spatial decoupling of valley farming and upland grazing. This phenomenon might be partly to blame for patterns of land tenure litigation and conflict observed in our study area. If, as our data suggest, upland stocking rates are mostly regulated by the ability of farmers to feed their livestock through the winter, El Rito would have been the site where valley regulation of upland stocking rates should have been strongest. Yet associations of permitees who graze their livestock on allotments above El Rito have exhibited the highest levels of litigation and opposition to USFS grazing regulations in the recent past (e.g., [36]). We speculate that an increasing number of these permitees own base properties outside of the El Rito valley, the least productive of our study sites. This valley-upland decoupling has possibly led to a situation of relaxed winter forage constraints, increased demand for summer forage on public lands, and a logical increase in the levels of litigation and conflict. Interestingly, allotments above El Rito were the only ones to show an increase in stocking rates over the past 30 years. Further research will be needed to determine the connections between 
spatial proximity of valley hay production and upland grazing lands and the resilience of acequia agropastoral systems.

\section{Conclusions}

Our study was exploratory in nature and included a small (yet significant) sample of the estimated 800 acequias in existence in north-central New Mexico and southern Colorado [11]. Nonetheless, to our knowledge, ours was the first to address the valley-upland system as a whole. As such, our study makes original contributions to the understanding of traditional agropastoral systems in the southwestern USA. The resilience of these systems appears to depend on close connection of uplands and valleys which apparently occurs at multiple levels. At the most basic level, hydrological connection between the upland watershed and downstream valleys allows for crop/hay production and household water provisioning [22]. Spatial connectivity is obviously essential at this level. At another level, there appear to be livestock-mediated connections that allow integrating forage productivity of upland rangelands and downstream valleys. Increased snowmelt in the upland forests yields more water in the valley acequias leading to higher hay production, which can promote growth in livestock numbers. The opposite occurs in years of water scarcity. This agro-biophysical feedback loop perhaps lies at the core of the resilience and sustainability of traditional agropastoral communities of northern New Mexico. Spatial decoupling of valley and adjacent rangeland agricultural activities could short-circuit this hypothesized water-mediated feedback loop and cause a breakdown in the system's ability to self-regulate and persist, a phenomenon that should be considered in future allocation of public rangeland livestock grazing permits.

Supplementary Materials: The following are available online at http:/ / www.mdpi.com/2071-1050/10/6/2021/ s1; Figure S1: Map of study sites; Table S1: Survey questionnaire; Table S2: Coding of questionnaire responses for analysis.

Author Contributions: S.C.L. conducted the surveys, gathered historical data, prepared data for analysis, and developed a first draft of the manuscript. A.F.C. designed the study, conducted statistical analyses, and developed the final draft of the manuscript. U.R.S. helped develop questionnaires and conduct surveys. S.J.G., A.G.F., and C.G.O. played a critical role in study design and provided input into manuscript development. K.G.B. provided land cover data for New Mexico and helped develop the final draft of the manuscript. L.C. provided crucial expertise and input on survey data interpretation.

Funding: This research was funded with a grant from the National Science Foundation Coupled Natural Human Systems Program (\# 1010516 to Fernald et al.). Partial support was provided by the New Mexico Agricultural Experiment Station, the United States Department of Agriculture, National Institute of Food and Agriculture, Hatch Project 1000985 (Cibils).

Acknowledgments: Authors wish to thank Lee Hamilton, Vince Tidwell, Jose Rivera, Sylvia Rodriguez, and Brian Hurd, and David Archuleta, Tony Valdez, Pat Torres, Edmund Gomez, John Miera, and Palemón Martinez for invaluable comments and suggestions which greatly improved our survey instrument. We are indebted to Kendall Clark, Diana Trujillo, John Miera, Jack Carpenter, Buck Sanchez, and Michael Casados of the United States Forest Service Carson National Forest and James Harmon, Sam DesGeorges, and Ernesto Hurtado of the Bureau of Land Management Taos Office for facilitating access to allotment data. The Northern New Mexico Stockman's Association generously provided the opportunity for us to deliver surveys at their 2013 annual meeting in Taos, and Joseph Garcia and Tony Valdez were instrumental in helping us conduct surveys among farmers in our study area. We also thank three anonymous reviewers who provided valuable comments that helped improve an earlier version of this manuscript.

Conflicts of Interest: The authors declare no conflict of interest.

\section{References}

1. Herrero, M.; Thornton, P.K.; Notenbaert, A.M.; Wood, S.; Msangi, S.; Freeman, H.A.; Bossio, D.; Dixon, J.; Peters, M.; van de Steeg, J.; et al. Smart Investments in Sustainable Food Production: Revisiting Mixed Crop-Livestock Systems. Science 2010, 327, 822-825. [CrossRef] [PubMed]

2. Thornton, P.K.; Kruska, R.L.; Henninger, N.; Kristjanson, P.M.; Reid, R.S.; Robinson, T.P. Locating poor livestock keepers at the global level for research and development targeting. Land Use Policy 2003, 20, 311-322. [CrossRef] 
3. Alary, V.; Corniaux, C.; Gautier, D. Livestock's Contribution to Poverty Alleviation: How to Measure It? World Dev. 2011, 39, 1638-1648. [CrossRef]

4. McDermott, J.J.; Staal, S.J.; Freeman, H.A.; Herrero, M.; Van de Steeg, J.A. Sustaining intensification of smallholder livestock systems in the tropics. Livest. Sci. 2010, 130, 95-109. [CrossRef]

5. Herrero, M.; Thornton, P.K. Livestock and global change: Emerging issues for sustainable food systems. Proc. Natl. Acad. Sci. USA 2013, 110, 20878-20881. [CrossRef] [PubMed]

6. Ostrom, E. Governing the Commons: The Evolution of Institutions for Collective Action; Cambridge University Press: Cambridge, UK; New York, NY, USA, 1990; p. 280.

7. Baumgärtner, J.; Tikubet, G.; Gilioli, G. Towards Adaptive Governance of Common-Pool Mountainous Agropastoral Systems. Sustainability 2010, 2, 1448. [CrossRef]

8. Netting, R.M. What alpine peasants have in common: Observations on communal tenure in a Swiss village. Hum. Ecol. 1976, 4, 135-146. [CrossRef]

9. López, M.M. Landscapes of northern Spain and pastoral systems. In Pasture Landscapes and Nature Conservation; Redecker, B., Härdtle, W., Finck, P., Riecken, U., Schröder, E., Eds.; Springer: Berlin/Heidelberg, Germany, 2002; pp. 67-86.

10. Schnabel, S.; Goncalves Ferreira, A.A.C. Sustainability of Agrosilvopastoral Systems: Dehesas, Montados; Catena Verlag: Reiskirchen, Germany, 2004.

11. Rivera, J.A. Acequia Culture: Water, Land, and Community in the Southwest, 1st ed.; University of New Mexico Press: Albuquerque, NM, USA, 1998.

12. Fernald, A.; Tidwell, V.; Rivera, J.; Rodríguez, S.; Guldan, S.; Steele, C.; Ochoa, C.; Hurd, B.; Ortiz, M.; Boykin, K.; Cibils, A. Modeling Sustainability of Water, Environment, Livelihood, and Culture in Traditional Irrigation Communities and Their Linked Watersheds. Sustainability 2012, 4, 2998. [CrossRef]

13. Ortiz, M.; Brown, C.; Fernald, A.S.; Baker, T.T.R.; Creel, B.; Guldan, S. Land Use Change Impacts on Acequia Water Resources in Northern New Mexico. J. Contemp. Water Res. Educ. 2007, 137, 47-54. [CrossRef]

14. Fernald, A.; Guldan, S.; Boykin, K.; Cibils, A.; Gonzales, M.; Hurd, B.; Lopez, S.; Ochoa, C.; Ortiz, M.; Rivera, J.; et al. Linked hydrologic and social systems that support resilience of traditional irrigation communities. Hydrol. Earth Syst. Sci. 2015, 19, 293-307. [CrossRef]

15. Rivera, J.A. Irrigation Communities of the Upper Rio Grande Bioregion: Sustainable Resource Use in the Global Context. Nat. Resour. J. 1996, 36, 731-760.

16. Rodríguez, S. Acequia: Water-Sharing, Sanctity, and Place, 1st ed.; School for Advanced Research Press: Santa Fe, NM, USA, 2006.

17. Cox, M. Exploring the Dynamics of Social-Ecological Systems: The Case of the Taos Valley Acequias. Ph.D. Thesis, Indiana University, Bloomington, Indiana, 2010.

18. Eastman, C.; King, J.P.; Meadows, N.A. Acequias, Small Farms, and the Good Life. Cult. Agric. 1997, 19, 14-23. [CrossRef]

19. Fernald, A.G.; Baker, T.T.; Guldan, S.J. Hydrologic, riparian, and agroecosystem functions of traditional Acequia irrigation systems. J. Sustain. Agric. 2007, 30, 147-171. [CrossRef]

20. Fernald, A.G.; Cevik, S.Y.; Ochoa, C.G.; Tidwell, V.C.; King, J.P.; Guldan, S.J. River Hydrograph Retransmission Functions of Irrigated Valley Surface Water-Groundwater Interactions. J. Irrig. Drain. Engi. ASCE 2010, 136, 823-835. [CrossRef]

21. Helmus, A.M.; Fernald, A.G.; VanLeeuwen, D.M.; Abbott, L.B.; Ulery, A.L.; Baker, T.T. Surface water seepage effects on shallow ground-water quality along the Rio Grande in northern New Mexico. J. Am. Water Resour. Assoc. 2009, 45, 407-418. [CrossRef]

22. Ochoa, C.G.; Fernald, A.G.; Guldan, S.J.; Tidwell, V.C.; Shukla, M.K. Shallow Aquifer Recharge from Irrigation in a Semiarid Agricultural Valley in New Mexico. J. Hydrol. Eng. 2013, 18, 1219-1230. [CrossRef]

23. Ochoa, C.G.; Fernald, A.G.; Guldan, S.J.; Shukla, M.K. Deep percolation and its effects on shallow groundwater level rise following flood irrigation. Trans. ASABE 2007, 50, 73-81. [CrossRef]

24. Cox, M.; Ross, J.M. Robustness and vulnerability of community irrigation systems: The case of the Taos valley acequias. J. Environ. Econ. Manag. 2011, 61, 254-266. [CrossRef]

25. Mayagoitia, L.; Hurd, B.; Rivera, J.; Guldan, S. Rural Community Perspectives on Preparedness and Adaptation to Climate-Change and Demographic Pressure. J. Contemp. Water Res. Educ. 2012, 147, 49-62. [CrossRef] 
26. Eastman, C.; Gray, J.R. Community Grazing: Practice and Potential in New Mexico, 1st ed.; University of New Mexico: Albuquerque, NM, USA, 1987.

27. Eastman, C.; Raish, C.; McSweeney, A. Small livestock operations in northern New Mexico. In Livestock Management in the American Southwest: Ecology, Society, and Economics; Jamison, R., Raish, C., Eds.; Elsevier: Amsterdam, The Netherlands, 2000; pp. 523-554.

28. Raish, C.; McSweeney, A.M. Land Grants and the U. S. Forest Service. Nat. Resour. J. 2008, 48, 1039-1055.

29. Raish, C.; McSweeney, A. Livestock ranching and traditional culture in northern New Mexico. Nat. Resour. J. 2001, 41, 713-730.

30. McSweeney, A.M.; Raish, C. Social, Cultural, and Economic Aspects of Livestock Ranching on the Santa Fe and Carson National Forests; RMRS GTR 276; USFS: Fort Collins, CO, USA, 2012; p. 199.

31. Ochoa, C.G.; Guldan, S.J.; Cibils, A.F.; Lopez, S.C.; Boykin, K.G.; Tidwell, V.C.; Fernald, A.G. Hydrologic Connectivity of Head Waters and Floodplains in a Semi-Arid Watershed. J. Contemp. Water Res. Educ. 2013, 152, 69-78. [CrossRef]

32. Dunmire, W.W. New Mexico's Spanish Livestock Heritag: Four Centuries of Animals, Land, and People; University of New Mexico Press: Albuquerque, NM, USA, 2013.

33. Ebright, M. Land Grants and Lawsuits in Northern New Mexico, 1st ed.; University of New Mexico Press: Albuquerque, NM, USA, 1994.

34. Government Accountability Office (US-GAO). Treaty of Guadalupe Hidalgo: Definition and List of Community Land Grants in New Mexico; GAO-01-951; US-GAO: Washington, DC, USA, 2001; p. 59.

35. Tucker, J. Feds File Motion to Weaken Rancher's Claim. Available online: http://nmflc.blogspot.com/2012/ 11/feds-file-motion-to-weaken-ranchers.html (accessed on 14 June 2018).

36. Schultz, E. Lawsuit against Forest Service Moves forward. Available online: https:/ /lajicarita.wordpress. com/2013/01/29/lawsuit-against-forest-service-moves-forward/ (accessed on 14 June 2018).

37. Reid, R.S.; Fernández-Giménez, M.E.; Galvin, K.A. Dynamics and Resilience of Rangelands and Pastoral Peoples Around the Globe. Annu. Rev. Environ. Resour. 2014, 39, 217-242. [CrossRef]

38. Huntsinger, L.; Forero, L.C.; Sulak, A. Transhumance and pastoralist resilience in the Western United States. Pastoralism 2010, 1, 9-36.

39. Pearce, T.M. New Mexico Place Names: A Geographical Dictionary; University of New Mexico Press: Albuquerque, NM, USA, 1980.

40. WRRC Climate of New Mexico. Available online: https://wrcc.dri.edu/narratives/NEWMEXICO.htm (accessed on 14 June 2018).

41. Walker, B.; Holling, C.S.; Carpenter, S.R.; Kinzig, A.P. Resilience, adaptability and transformability in social-ecological systems. Ecol. Soc. 2004, 9, 5. [CrossRef]

42. USDA-NASS. Livestock Invebtory and Hay Production Data for Taos and Rio Arriba Counties in New Mexico. Available online: https: / quickstats.nass.usda.gov / (accessed on 14 June 2018).

43. NOAA-NCDC. Palmer Drought Indices. Available online: https://www.drought.gov/drought/sites/ drought.gov.drought/files/GWP_Handbook_of_Drought_Indicators_and_Indices_2016.pdf (accessed on 14 June 2018).

44. USGS Provisional Digital Land Cover Map for the Southwestern United States. Version 1.0. RS/GIS Laboratory, College of Natural Resources, Utah State University. Available online: swregap.nmsu.edu/ HMdatabase/landc_database_report.pdf/ (accessed on 14 June 2018).

45. USFS. Carson National Forest rmu_unit (allotments) GIS Data. Available online: https:/ /www.fs.usda.gov / detail/r3/landmanagement/gis/?cid=stelprdb5202766 (accessed on 14 June 2018).

46. USDI-BLM. Data Basin—Bureau of Land Management (BLM) Grazing Allotments in New Mexico. Available online: https:/ / databasin.org/datasets/19c6818a555743ae9ca06996f123abea (accessed on 14 June 2018).

47. CattleFax. USDA Cattle Price Data. Available online: https:/ / www.cattlefax.com/ (accessed on 14 June 2018).

48. Patton, M.Q. Qualitative Research and Evaluation Methods, 4th ed.; SAGE: Los Angeles, CA, USA, 2015.

49. Bernard, H.R. Research Methods in Anthropology: Qualitative and Quantitative Approaches, 4th ed.; AltaMira Press: Lanham, MD, USA, 2006.

50. Bailey, K.D. Methods of Social Research; Free Press: New York, NY, USA, 1978.

51. Anadón, J.D.; Sala, O.E.; Turner, B.L.; Bennett, E.M. Effect of woody-plant encroachment on livestock production in North and South America. Proc. Natl. Acad. Sci. USA 2014, 111, 12948-12953. [CrossRef] [PubMed] 
52. Roncoli, C.; Jost, C.; Perez, C.; Moore, K.; Ballo, A.; Cissé, S.; Ouattara, K. Carbon sequestration from common property resources: Lessons from community-based sustainable pasture management in north-central Mali. Agric. Syst. 2007, 94, 97-109. [CrossRef]

53. Turner, M.D. Capital on the move: The changing relation between livestock and labor in Mali, West Africa. Geoforum 2009, 40, 746-755. [CrossRef]

54. Turner, M.; McPeak, J.; Ayantunde, A. The Role of Livestock Mobility in the Livelihood Strategies of Rural Peoples in Semi-Arid West Africa. Hum. Ecol. 2014, 42, 231-247. [CrossRef]

55. Priya, D. Environmental risk, resilience and migration: Implications for natural resource management and agriculture. Environ. Res. Lett. 2012, 7, 015603.

56. Davis, J.; Lopez-Carr, D. Migration, remittances and smallholder decision-making: Implications for land use and livelihood change in Central America. Land Use Policy 2014, 36, 319-329. [CrossRef] [PubMed]

57. Neely, C.; Bunning, S.; Wilkes, A. Managing dryland pastoral systems: Implications for mitigation and adaptation to climate change. In Grassland Carbon Sequestration: Management, Policy and Economics; Abberton, M., Conant, R., Batello, C., Eds.; FAO: Rome, Italy, 2010; pp. 235-266.

58. Holechek, J.L.; Pieper, R.D.; Herbel, C.H. Range Management Principles and Practices, 6th ed.; Prentice Hall: Upper Saddle River, NJ, USA, 2011; p. 607.

(C) 2018 by the authors. Licensee MDPI, Basel, Switzerland. This article is an open access article distributed under the terms and conditions of the Creative Commons Attribution (CC BY) license (http:/ / creativecommons.org/licenses/by/4.0/). 